\title{
KELANGSUNGAN HIDUP DAN PERTUMBUHAN LARVA RAJUNGAN (Portunus pelagicus) MELALUI PEMBERIAN NAUPLIUS Artemia YANG DIPERKAYA DENGAN MINYAK IKAN DAN MINYAK JAGUNG
}

\section{[Survival Rate and Growth of Blue Swimming Crab (Portunus pelagicus) Larvae Fed by Artemia nauplii Enriched with Fish Oil and Corn Oil]}

\author{
Katisya Abrina Prastyanti ${ }^{1}$, Ayi Yustiati ${ }^{1}$, Sunarto ${ }^{1}$, Yuli Andriani ${ }^{1}$ \\ ${ }^{1}$ Program Studi Perikanan, Fakultas Perikanan dan IImu Kelautan \\ Universitas Padjadjaran \\ Email korespondensi : yuli.andriani@unpad.ac.id
}

\begin{abstract}
Abstrak
Tujuan penelitian ini adalah untuk mengetahui kelangsungan hidup dan pertumbuhan larva rajungan ( $P$. pelagicus) melalui pemberian nauplius Artemia yang diperkaya dengan minyak ikan dan minyak jagung. Penelitian ini dilakukan di Panti Pembenihan Family Portunidae, Balai Besar Perikanan Budidaya Air Payau (BBPBAP) Jepara, Jawa Tengah. Larva yang baru menetas (zoea 1) dipelihara dalam wadah plastik $20 \mathrm{~L}$ yang diisi $15 \mathrm{~L}$ air laut dengan kepadatan larva 50 ind/L. Penelitian ini menggunakan Rancangan Acak Lengkap (RAL) dengan enam perlakuan dengan tiga kali ulangan, yaitu : A (tanpa pengayaan), B (100\% minyak ikan $+0 \%$ minyak jagung), $C$ (75\% minyak ikan $+25 \%$ minyak jagung), D (50\% minyak ikan $+50 \%$ minyak jagung), E ( $25 \%$ minyak ikan $+75 \%$ minyak jagung), $F(0 \%$ minyak ikan $+100 \%$ minyak jagung). Parameter utama yang diamati adalah kelangsungan hidup dan pertumbuhan panjang mutlak. Analisis statistik dilakukan dengan analisis ragam (ANOVA) dan uji jarak berganda Duncan taraf kepercayaan 95\%. Hasil penelitian menunjukkan bahwa perlakuan memberikan pengaruh nyata terhadap kelangsungan hidup dan pertumbuhan larva $P$. pelagicus. Pemberian nauplius Artemia yang diperkaya $75 \%$ minyak ikan dan $25 \%$ minyak jagung mempunyai kelangsungan hidup terbaik sebesar $12,89 \%$ dengan pertumbuhan panjang mutlak sebesar $2,12 \mathrm{~mm}$.
\end{abstract}

Kata kunci : $\quad$ kelangsungan hidup, pertumbuhan, Portunus pelagicus, Nauplius artemia yang diperkaya, minyak ikan, minyak jagung

\begin{abstract}
This research was conducted to determine survival rate and growth of blue swimming crab larvae ( $P$. pelagicus) fed by enriched Artemia nauplii with fish oil and corn oil. This research was conducted at the Portunidae Hatchery in Brackishwater Aquaculture Development Center (BBPBAP) Jepara, Central Java. Newly heatched larvae (zoea 1) were cultured in 20 L plastic tank that filled $15 \mathrm{~L}$ of seawater with a density of 50 ind/L. This research used Completely Randomized Design (CRD) with six treatments and three replications: A (without enrichment), B (100\% fish oil + $0 \%$ corn oil), C ( $75 \%$ fish oil $+25 \%$ corn oil), D (50\% fish oil + 50\% corn oil), E ( $25 \%$ fish oil $+75 \%$ corn oil), $F$ ( $0 \%$ fish oil $+100 \%$ corn oil). The main parameters were observed on survival rate and growth of total body length. Statistical analysis was performed with analysis of variance (ANOVA) and Duncan's multiple range test at the $95 \%$ level of confidence. The results showed that the treatment gives significant effect on survival rate and growth of $P$. pelagicus larvae $(P<0,05)$. Larva fed by enriched Artemia nauplii with $75 \%$ fish oil and $25 \%$ corn oil had the best survival rate at $12,89 \%$ and growth of total body length at $2,12 \mathrm{~mm}$.
\end{abstract}

Key words: $\quad$ survival rate, growth, Portunus pelagicus, enriched Artemia Nauplii, fish oil, corn oil

\section{PENDAHULUAN}

Rajungan (Portunus pelagicus) merupakan salah satu sumberdaya perikanan Indonesia yang mempunyai potensi besar untuk menjadi komoditas ekspor unggulan non migas. Permintaan rajungan terus mengalami peningkatan setiap tahunnya. Berdasarkan data statistik Dirjen Pengolahan dan Pemasaran Hasil Perikanan (2012), pada tahun 2011 nilai ekspor kepiting dan rajungan menempati urutan ketiga setelah udang dan tuna. Sebagian besar kebutuhan ekspor rajungan diperoleh dari hasil tangkapan di alam.

Upaya untuk menjaga populasi rajungan di alam adalah dengan kegiatan budidaya. Kegiatan pembenihan rajungan saat ini masih mengalami kendala yaitu ketersediaan benih yang tidak stabil akibat tingginya mortalitas terutama pada stadia larva dan salah satu penyebabnya adalah rendahnya kualitas pakan yang diberikan (Effendy et al. 2005).

Nauplius Artemia sebagai salah satu pakan larva rajungan harus memiliki kandungan nutrisi yang sesuai dengan kebutuhan larva. Beberapa penelitian menyatakan bahwa kandungan asam lemak esensial Artemia sangat rendah (Sorgeloos et al. 2001). Asam lemak esensial mempunyai peranan yang penting sebagai komponen fosfolipid, hormon, aktivasi enzim dan prekursor prostaglandin (Akiyama dan Dominy, 1980).

Penambahan asam lemak esensial pada Artemia dapat dilakukan menggunakan emulsi minyak yang mempunyai kandungan asam lemak esensial tinggi 
(Sorgeloos et al. 2001). Sumber lemak hewani dan nabati seperti minyak ikan dan minyak jagung sudah umum digunakan untuk menambah kandungan asam lemak esensial pada pakan alami dan telah berhasil meningkatkan kelangsungan hidup dan pertumbuhan beberapa spesies ikan (Kanazawa 1985 dan Watanabe et al. 1988). Oleh sebab itu penelitian ini dilakukan untuk mengetahui kelangsungan hidup dan pertumbuhan larva rajungan ( $P$. pelagicus) melalui pemberian nauplius Artemia yang diperkaya dengan minyak ikan dan minyak jagung.

\section{BAHAN DAN METODE}

Penelitian dilaksanakan pada 4 Mei sampai 2 Juni 2016, bertembat di Panti Pembenihan Portunidae, Balai Besar Pengembangan Budidaya Air Payau (BBPBAP) Jepara, Jawa Tengah.

Penelitian ini menggunakan Rancangan Acak Lengkap (RAL) dengan enam perlakuan dengan tiga kali ulangan, yaitu : A (tanpa pengayaan), B (100\% minyak ikan $+0 \%$ minyak jagung), C (75\% minyak ikan $+25 \%$ minyak jagung), D (50\% minyak ikan $+50 \%$ minyak jagung), $E$ ( $25 \%$ minyak ikan $+75 \%$ minyak jagung), F (0\% minyak ikan + $100 \%$ minyak jagung).

Hewan uji yang digunakan adalah larva rajungan yang baru menetas (zoea 1). Larva ditebar dengan kepadatan 50 ind/L air media yang dipelihara hingga mencapai megalopa. Pakan uji yang digunakan berupa nauplius Artemia yang telah diperkaya sesuai perlakuan. Pemberian nauplius Artemia dilakukan dengan kepadatan 2,5 ind $/ \mathrm{mL}$. Rotifera dan Chlorella juga diberikan sebagai pakan tambahan dengan kepadatan masing-masing 5 ind $/ \mathrm{mL}$ dan 300-400 sel/mL. Rotifera dan Chlorella diambil dari wadah kultur massal dan diberikan pada pukul 08.00 WIB.

Pemeliharaan larva rajungan dilakukan menggunakan wadah berupa ember plastik berwarna hitam kapasitas $20 \mathrm{~L}$ dilengkapi dengan instalasi aerasi. Setiap wadah diisi air media sebanyak 15 liter. Pergantian air dengan salinitas 30 ppm dilakukan setiap pagi hari sebanyak $10 \%$ dari volume total.

Pengayaan nauplius Artemia dilakuan pada kepadatan 300.000 ind/L. Setelah pengayaan selama 6 jam, nauplius Artemia dipanen dengan plankton net dan dicuci bersih sebelum diberikan kepada larva rajungan. Pemberian nauplius Artemia dilakukan dua kali sehari yaitu pada pukul 11.00 dan 19.00 WIB.

Parameter utama meliputi kelangsungan hidup dan pertumbuhan panjang mutlak. Kelangsungan hidup larva dihitung menggunakan rumus Effendie (1979):

$$
\mathrm{SR}=\frac{N t}{N o} X 100 \%
$$

$\mathrm{SR}=$ Kelangsungan hidup (\%)

$\mathrm{Nt}=$ Jumlah larva pada waktu ke-t (ekor)

No = Jumlah larva awal (ekor)

Pertumbuhan panjang mutlak dihitung berdasarkan rumus Effendie (1979):

$$
\Delta \mathbf{L}=\mathbf{L t}-\mathbf{L o}
$$

$\Delta \mathrm{L} \quad=$ Pertumbuhan panjang mutlak $(\mathrm{mm})$

$\mathrm{Lt} \quad=$ Panjang rata-rata pada hari ke-t $(\mathrm{mm})$

Lo = Panjang rata-rata pada awal penelitian $(\mathrm{mm})$

Parameter penunjang meliputi laju perkembangan larva dan kualitas air terdiri dari suhu, salinitas, pH, oksigen terlarut, dan amoniak. Laju perkembangan larva di-hitung melalui Indeks Perkembangan Larva (IPL) sesuai dengan rumus Ikhwanuddin (2012):

$$
\mathbf{I P L}=\frac{\left[\left(\mathbf{Z}_{\mathbf{0}} \times \mathbf{n}_{\mathbf{0}}\right)+\left(\mathbf{Z}_{\mathbf{0 + 1}} \times \mathbf{n}_{\mathbf{0 + 1}}\right)\right]}{\mathbf{N}}
$$

IPL = Indeks perkembangan larva

$\mathrm{Z}_{0} \quad$ = Nilai stadia awal

$\mathrm{n}_{0} \quad=$ Jumlah larva stadia awal

$\mathrm{Z}_{0+1}=$ Nilai satu stadia berikutnya

$\mathrm{n}_{0+1}=$ Jumlah larva pada stadia berikutnya

$\mathrm{N} \quad=$ Jumlah total larva disampling

Data tingkat kelangsungan hidup dan pertumbuhan panjang mutlak ditabulasi dan dianalisis menggunakan analisis ragam (ANOVA), kemudian dilanjutkan dengan uji jarak berganda Duncan pada taraf kepercayan 95\% untuk mengetahui perbedaan antar perlakuan (Gaspersz, 1991). Data indeks perkembangan larva dan kualitas air dianalisis menggunakan analisis deskriptif.

\section{HASIL DAN PEMBAHASAN}

Hasil pengamatan terhadap kelangsungan hidup, pertumbuhan panjang mutlak dan laju perkembangan larva dari stadia zoea 1 hingga mencapai megalopa disajikan pada Tabel 1. Hasil analisis ragam menujukkan bahwa pemberian nauplius Artemia yang diperkaya dengan minyak ikan dan minyak jagung memberikan pengaruh nyata $(P<0,05)$ terhadap kelangsungan hidup dan pertumbuhan panjang mutlak larva rajungan $(P$. pelagicus).

\section{Kelangsungan Hidup (\%)}

Kelangsungan hidup larva rajungan tertinggi dicapai pada perlakuan C (Tabel 1). Tingginya kelangsungan hidup yang dicapai pada perlakuan $\mathrm{C}$ disebabkan oleh kandungan nutrisi terutama asam lemak dalam tubuh nauplius Artemia pada perlakuan tersebut telah memenuhi kebutuhan larva untuk mempertahankan kelangsungan hidupnya secara optimal. Menurut Mursitorini (2006), larva kepiting bakau membutuhkan asam lemak esensial sebesar $1 \%$ dari total pakan untuk pertumbuhan dan kelangsungan hidup yang optimal. Lebih lanjut menurut Karlina (1999), pemberian asam lemak dalam jumlah yang sesuai dengan kebutuhan larva berperan penting dalam merangsang daya tahan tubuh larva sehingga mengaktifkan fungsi kekebalan tubuh yang berpengaruh terhadap mudahnya beradaptasi dengan lingkungannya dan tahan terhadap serangan penyakit. 
Tabel 1. Kelangsungan Hidup, Pertumbuhan Panjang Mutlak dan Laju Perkembangan Larva Rajungan

\begin{tabular}{|c|c|c|c|}
\hline Perlakuan & $\begin{array}{c}\text { Kelangsungan } \\
\text { Hidup } \\
(\%) \\
\end{array}$ & $\begin{array}{c}\text { Pertumbuhan } \\
\text { panjang mutlak } \\
(\mathrm{mm})\end{array}$ & $\begin{array}{c}\text { Laju } \\
\text { perkembangan } \\
\text { (Zoea 1-Megalopa) }\end{array}$ \\
\hline A (tanpa pengayaan) & $7,78^{a}$ & $2,17^{c}$ & 10 hari \\
\hline $\mathrm{B}(100 \% \mathrm{MI}+0 \% \mathrm{MJ})$ & $11,96^{\mathrm{cd}}$ & $2,21^{c}$ & 9 hari \\
\hline $\mathrm{C}(75 \% \mathrm{MI}+25 \% \mathrm{MJ})$ & $12,89^{d}$ & $2,12^{\mathrm{bc}}$ & 10 hari \\
\hline D (50\% MI + 50\% MJ) & $10,76^{\mathrm{bc}}$ & $1,96^{\mathrm{ab}}$ & 10 hari \\
\hline $\mathrm{E}(25 \% \mathrm{MI}+75 \% \mathrm{MJ})$ & $9,29^{a b}$ & $1,97^{a b}$ & 10 hari \\
\hline $\mathrm{F}(0 \% \mathrm{MI}+100 \% \mathrm{MJ})$ & $8,09^{a}$ & $1,86^{a}$ & 10 hari \\
\hline
\end{tabular}

Hasil kelangsungan hidup larva rajungan pada perlakuan $C$ tidak berbeda nyata $(P<0,05)$ dengan perlakuan B. Hal ini berarti bahwa kandungan nutrisi dalam tubuh nauplius Artemia yang dikonsumsi oleh larva rajungan pada perlakuan $\mathrm{C}$ dan $\mathrm{B}$ tidak jauh berbeda. Walaupun perlakuan $\mathrm{C}$ dan $\mathrm{B}$ tidak berbeda nyata $(P>0,05)$, namun hal ini membuktikan bahwa penggunaan $25 \%$ minyak jagung masih menghasilkan kelangsungan hidup larva rajungan yang relatif lebih tinggi dibandingkan perlakuan lainnya.

Peningkatan komposisi minyak jagung diatas $25 \%$ pada perlakuan $D, E$ dan $F$ memberikan kelangsungan hidup larva ranjungan yang lebih rendah dari perlakuan B dan C. Hal ini karena penggunaan komposisi minyak jagung yang cukup tinggi dalam proses pengayaan diduga menambah kandungan asam lemak $\omega 6$ pada naulius Artemia. Terdapat kecenderungan bahwa larva rajungan yang mengonsumsi nauplius Artemia dengan kandungan $\omega 6$ yang lebih tinggi mempunyai kelangsungan hidup lebih rendah. Menurut Watanabe (1988), kebutuhan asam lemak $\omega 3$ lebih besar dibandingkan asam lemak $\omega 6$ pada kebanyakan ikan laut. Lebih lanjut Furuita et al. (1996) menyatakan bahwa ikan yang diberi pakan dengan kandungan asam lemak $\omega 3$ HUFA yang rendah mempunyai daya tahan tubuh rendah dan kematian yang tinggi.

Kelangsungan hidup larva rajungan yang dihasilkan pada perlakuan A (tanpa pengayaan) merupakan yang terendah dari perlakuan lainnya dengan rata-rata $7,78 \%$. Rendahnya kelangsungan hidup tersebut disebabkan oleh tidak adanya penambahan nilai nurisi terutama asam lemak esensial pada nauplius Artemia, sehingga tidak dapat memenuhi kebutuhan larva rajungan untuk mendukung kelangsungan hidupnya. Kompyang dan Ilyas (1988) menyatakan bahwa kekurangan asam lemak esensial dalam pakan akan menyebabkan pertumbuhan yang rendah, menurunnya efisiensi pakan dan dapat meningkatkan angka kematian ikan.

\section{Pertumbuhan Panjang Mutlak}

Pertumbuhan panjang mutlak larva rajungan tertinggi dihasilkan pada perlakuan B. Tingginya pertumbuhan panjang mutlak pada perlakuan B diduga disebabkan oleh tingginya kandungan asam lemak $\omega 3$ terutama EPA dan DHA pada nauplius Artemia. Ketersediaan asam lemak $\omega 3$ HUFA pada nauplius Artemia yang dikonsumsi larva rajungan digunakan tubuh sebagai sumber energi yang diperoleh dari hasil konversi menjadi ATP melalui proses $\beta$ oksidasi dalam mitokondria yang merupakan sumber energi potensial untuk keseluruhan aktivitas biologi (Dhert, 1991). Lebih lanjut Lovell (1988) dalam Khasanah et al. (2012) menyatakan bahwa kebutuhan energi untuk metabolisme harus dipenuhi terlebih dahulu dan apabila berlebihan maka digunakan untuk pertumbuhan.

Pertumbuhan panjang mutlak tertinggi pada perlakuan B tidak berbeda nyata dengan perlakuan $A$ dan $C$. Perlakuan $C$ yang menghasilkan kelangsungan hidup larva rajungan tertinggi belum menghasilkan pertumbuhan panjang mutlak yang lebih tinggi dari perlakuan B. Hal ini disebabkan oleh komposisi minyak ikan yang digunakan pada perlakuan B lebih tinggi dari perlakuan C, sehingga nauplius Artemia pada perlakuan $B$ mempunyai kandungan $\omega 3$ terutama EPA yang lebih tinggi. Artemia yang mempunyai kandungan asam lemak 20:3 $\omega 3$ (EPA) yang tinggi mampu mendukung pertumbuhan yang lebih baik bagi organisme laut jika dibandingkan dengan Artemia yang mempunyai kandungan asam lemak 20:3 $\omega 3$ (EPA) yang rendah (Fujita et al. 1980 dalam Syahrul, 1995)

Perlakuan D, $E$ dan $F$ menghasilkan pertumbuhan panjang mutlak yang relatif rendah dan ketiganya tidak berbeda nyata. Peningkatan komposisi minyak jagung yang mengandung sedikit $\omega 3$ dan lebih banyak $\omega 6$ sebagai bahan pengaya menyebabkan penurunan rasio $\omega 3 / \omega 6$, sehingga nilai nutrisi nauplius Artemia tidak sesuai dengan kebutuhan larva rajungan. Hal ini sesuai dengan pernyataan Kanazawa et al. (1979) bahwa pakan yang berisi sumber lemak nabati 
menghasilkan pertumbuhan yang lambat karena kekurangan $\omega 3$ HUFA.

Pertumbuhan panjang mutlak larva rajungan pada perlakuan A lebih rendah dari perlakuan B. Hal ini disebabkan tidak adanya penambahan kandungan nutrisi pada nauplius Artemia terutama asam lemak $\omega 3$ dan $\omega 6$. Artemia mengandung EPA yang rendah dan bahkan tidak mengandung DHA pada tubuhnya (Sorgeloos et al. 2001). Rendahnya kandungan asam lemak esensial pada nauplius Artemia diduga kurang mencukupi kebutuhan larva rajungan untuk mendukung pertumbuhannya. Hal ini sesuai dengan pernyataan Furuita et al. (1996) menyatakan bahwa kekurangan asam lemak esensial akan mengakibatkan terganggunya pertumbuhan dan kelangsungan hidup larva.

Pertumbuhan panjang mutlak larva rajungan pada perlakuan A relatif tinggi dan tidak berbeda nyata dengan perlakuan B dan C. Hal ini diduga disebabkan oleh kepadatan larva yang menurun akibat mortalitas yang tinggi pada perlakuan A sehingga mengurangi persaingan untuk mendapatkan makanan dan ruang gerak. Hal ini sesuai dengan Syahid et al. (2006) yang menyatakan dengan kepadatan rendah ikan mempunyai kemampuan memanfaatkan makanan dengan baik dibandingkan dengan kepadatan yang cukup tinggi, karena makanan merupakan faktor luar yang mempunyai peranan di dalam pertumbuhan.

\section{Indeks Perkembangan Larva}

Perkembangan stadia larva rajungan pada perlakuan B relatif lebih cepat dibandingkan dengan perlakuan lainnya. Hasil ini berbanding lurus dengan hasil pengukuran pertumbuhan. Tingginya prtumbuhan panjang mutlak dan perkembangan larva rajungan pada perlakuan B disebabkan oleh kandungan w3 terutama
EPA dan DHA dalam tubuh nauplius Artemia yang dikonsumsi larva rajungan pada perlakuan B mampu menyediakan energi lebih besar sehingga dapat dimanfaatkan oleh larva rajungan untuk mendukung pertumbuhan. Peningkatan pertumbuhan akan mendorong larva untuk melakukan pergantian kulit dan memasuki stadia berikutnya. Suprayudi et al. (2002) menyatakan bahwa rasio perbandingan antara EPA dan DHA dalam pakan merupakan ukuran penting dalam menentukan perkembangan dan kelangsungan hidup larva Scylla serrata.

Secara umum perkembangan larva rajungan dari stadia zoea 1 sampai megalopa pada penelitian ini berlangsung secara normal yaitu selama 9-10 hari. Sebagaimana menurut Susanto (2007) bahwa secara normal pertumbuhan larva rajungan melalui empat stadia zoea dan satu stadia megalopa yang memerlukan masa pemeliharaan selama 8-10 hari.

\section{Kualitas Air}

Hasil pengukuran parameter kualitas air dapat dilihat pada Tabel 2 .

Secara umum semua parameter masih berada pada kriteria layak untuk pemeliharaan larva rajungan. Namun hasil pengukuran suhu menunjukkan bahwa fluktuasi suhu harian mencapai hingga $4-5^{\circ} \mathrm{C}$. Perubahan suhu menyebabkan larva mengalami stres yang mengakibatkan pemanfaatan energi pakan untuk pertumbuhan, termasuk sintesis materi metabolisme dan kekebalan tubuh kepiting terganggu (Aslamyah dan Fujaya, 2010). Kandungan amoniak dalam air media pemeliharaan relatif tinggi. Tingginya kandungan amoniak tersebut karena tingginya kepadatan larva pada pemeliharaan, sehingga menghasilkan sisa metabolisme yang tinggi.

Tabel 2. Kisaran Kualitas Air Selama Penelitian

\begin{tabular}{cccccc}
\hline \multirow{2}{*}{ Perlakuan } & \multicolumn{5}{c}{ Parameter } \\
\cline { 2 - 6 } & $\begin{array}{c}\text { Suhu } \\
\left({ }^{\circ} \mathrm{C}\right)\end{array}$ & Salinitas (ppt) & $\mathrm{pH}$ & $\begin{array}{c}\mathrm{DO} \\
(\mathrm{mg} / \mathrm{L})\end{array}$ & $\begin{array}{c}\text { Amoniak } \\
(\mathrm{mg} / \mathrm{L})\end{array}$ \\
\hline A & $29,7-34,2$ & $30-32$ & $8,0-8,1$ & $4,3-4,9$ & $0,06-1,58$ \\
B & $29,6-34,2$ & $30-32$ & $8,0-8,1$ & $4,3-4,9$ & $0,06-2,15$ \\
C & $29,9-34,5$ & $30-32$ & 8,1 & $4,3-5,2$ & $0,06-2,79$ \\
D & $29,3-33,7$ & $30-31$ & $8,0-8,1$ & $4,3-5,1$ & $0,06-2,57$ \\
E & $29,7-34,3$ & $30-31$ & $8,0-8,1$ & $4,3-5,0$ & $0,06-1,54$ \\
F & $29,3-34,3$ & $30-31$ & $8,0-8,1$ & $4,3-4,8$ & $0,06-2,46$ \\
\hline Optimal & $29-34^{\text {a }}$ & $30-33^{\text {a }}$ & $7-8,5^{\text {b }}$ & $4-6^{c}$ & $0,03-0,06^{\text {d }}$ \\
\hline
\end{tabular}

Sumber: a. Juwana dan Romimohtarto (2000), b. Syahidah et al. (2003), c. Adi (2011), d. Juwana (1997) 


\section{KESIMPULAN}

Pemberian nauplius Artemia yang diperkaya dengan $75 \%$ minyak ikan dan $25 \%$ minyak menghasilkan kelangsungan hidup larva rajungan tertinggi sebesar $12,89 \%$ dengan pertumbuhan panjang mutlak sebesar 2,12 $\mathrm{mm}$.

\section{Saran}

Pemberian nauplius Artemia yang diperkaya dengan $75 \%$ minyak ikan dan $25 \%$ minyak jagung dapat digunakan untuk menunjang kelangsungan hidup dan pertumbuhan panjang mutlak yang optimal pada larva rajungan.

\section{DAFTAR PUSTAKA}

Akiyama, D. M dan W. G. Dominy. 1980. Penaeid Shrimp Nutrition for The Comercial Feed Industry. Paper Submitted for Publication. 50 hlm.

Aslamyah, S. dan Y. Fujaya. 2010. Stimulasi Molting dan Pertumbuhan Kepiting Bakau (Scylla sp.) Melalui Aplikasi Pakan Buatan Berbahan Dasar Limbah Pangan yang Diperkaya dengan Ekstrak Bayam. Jurusan Perikanan, Fakultas IImu Kelautan dan Perikanan, Universitas Hasanuddin. Jurnal IImu Kelautan Vol. 13 (3) : 170-178

Boyd, C. E. 1982. Water Quality Management for Pond Fish Culture. Elsivier Science Publishing, Amsterdam, Oxford., New York.313 hal.

Dhert, P. 1991. Improxed use in Artemia in larviculture of the tropical fish Lates calcalifer Bloch. And Siganus guttatus Bloch. Thesis. Agriculture Science. Gehn University Belgium. $190 \mathrm{hlm}$

Dirjen Pengolahan dan Pemasaran Hasil Perikanan. 2012. Statistik Ekspor Hasil Perikanan Tahun 2011. Kementrian Kelautan dan Perikanan.

Effendie, M. I. 1979. Biologi Perikanan. Yayasan Pustaka Nusantara, Yogyakarta.

Effendy, S., Faidar., Sudirman., dan E, Nurcahyono. 2005. Perbaikan Teknik Pemeliharaan Larva pada Produksi Massal Benih Rajungan (Portunus pelagicus). Penelitian Balai Budidaya Air Payau Takalar. 6:1-10.

Juwana, S. 1997. Tinjauan Tentang Perkembangan Penelitian Budidaya Rajungan (Portunus pelagicus). Jurnal Oseanografi LIPI, 22:1-12.

Juwana, S dan K. Romimohtarto. 2000. Rajungan Perikanan, Cara Budidaya dan Menu Masakan. Djambatan, Jakarta.

Kanazawa, A. 1979. Effect Docosahexaenoic Acid and Phospholipids on Stress Tolerance of Fish. Journal of Aquaculture, 155:135-148.
Kanazawa, A. 1985. Nutrition of Penaeid Prawn and Shrimp. Dalam: Taki, Y., J. H. Primavera, dan J. A. Uobrera (Ed.), Proceedings of The First International Conference on The Culture of Penaeid Prawn/Shrimp Aquaculture. Philippines. HIm 121-130.

Karlina, N. 1999. Pengaruh Pemberian Branchionus plicatilis of Muller, yang diperkaya Minyak Ikan Cod dengan Konsentrasi yang Berbeda terhadap Kelangsungan Hidup Udang Windu (Panaeus monodon). Skripsi. Fakultas Pertanian. Undiversitas Padjadjaran. $40 \mathrm{hlm}$

Kompyang, L. P. dan S. Ilyas. 1988. Nutrisi Ikan/Udang Relevansi untuk Larva/Induk. Prosiding Seminar Nasional Pembenihan Ikan dan Udang. Prosiding/Puslitbang NO 13/1988. Kerjasama Badan Penelitian dan Pengembangan Pertanian Unpad. Hal 30-45.

Mursitorini, E. 2006. Pengaruh Pengayaan Artemia spp. dengan EPA dan DHA terhadap Perumbuhan dan Tingkat Kelangsungan Hidup Larva Rajungan. Skripsi. Teknologi Institut Pertanian Bogor. Bogor. $35 \mathrm{hlm}$

Suprayudi MA, T Takeuchi, K Hamasaki, \& J Hirokawa. 2002 The effect of $n-3$ HUFA content in rotifer on the development and survival of mud crab, Scylla serrata, larvae. Japan Aquaculture Society, 50(2):205-212.

Susanto, B. 2007. Pertumbuhan, Sintasan dan Keragaan Zoea Sampai Megalopa Rajungan (Portunus pelagicus) Melalui Penurunan Salinitas. Jurnal Perikanan. IX(1):154-160

Syahidah, D., B. Susanto dan I. Setyadi. 2003. Percobaan Pemeliharaan Megalopa Rajungan Portunus pelagicus Sampai Menjadi Rajungan Muda (Crablet 1) dengan Kisaran Salinitas Berbeda. Balai Besar Riset Perikanan Budidaya Gondol.

Syahrul. 1995. "Bioenkapsulasi Artemia dengan w3HUFA dosis berbeda, pengaruhnya terhadap pertumbuhan dan kelangsungan hidup anakan Kuda Laut (Hippocampus sp). Skripsi. Universitas Gadjah Mada, Yogyakarta

Sorgeloos, P., P. Dhert dan P. Candreva. 2001. Use of The Brine Shrimp, Artemia sp. in Marine Fish Larviculture. Journal of Aquaculture 200: 147159.

Watanabe, T., T. Takeuchi, A. Kanazawa, C. Y. Cho dan M. Furuichi. 1988. Fish Nutrition and Mariculture. Tokyo. JICA Textbook The General Aquaculture Course. 